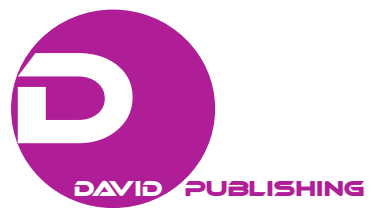

\title{
The Consolidation of Youth Lifestyle in the 1960s: Swinging London Through The Drapers' Record Magazine
}

\author{
Maíra Zimmermann \\ Armando Alvares Penteado Foundation (FAAP), São Paulo, Brazil \\ State University of Campinas (Unicamp), São Paulo, Brazil
}

\begin{abstract}
This paper discusses how consumerism boosted youth lifestyle in the 1960s-mainly through modern magazines (particularly in Britain) and built a territorial symbolic identity through fashion. In the 1960s, the consolidation of youth culture becomes an international phenomenon. With the development of ready-to-wear, adolescents begin to be target as a consumer market. The music and fashion industries unite to create and advertise youth lifestyle. The fashion shifts from Paris to London. Magazine articles and publicity set the latest trends. The method applied is research in primary source - the British journal The Drapers' Record-aiming to recognize fashion transformation and juvenilization in this period of time. The magazine shows ads and fashion editorials (mainly feminine), articles and news about fashion trend. There is also a brands guide for shoppers and retailers. The magazines used in the research are from 1964 to 1967, July and August issues, when the fall-winter trends are shown. From 1964 on, we notice the orientation towards a juvenile market and style, but these trends will only fully materialize through 1967. It leads to the conclusion that between 1965 and 1967 fashion juvenilization developed, reached its peak and global range.
\end{abstract}

Keywords: youth culture, 1960s, trend, media

\section{Introduction: Consolidation of Youth Culture in the 1960s}

In the 1960s, the consolidation of youth culture becomes an international phenomenon. With the development of ready-to-wear, adolescents begin to be targeted as a consumer market. The fashion center shifts from glamorous Paris, focused on couture, to hip London, based on King's Road and Carnaby Street's boutiques. The music and fashion industries unite to create and disseminate youth lifestyle, along with young designers and traders displaying the cultural effervescence of the moment on the streets: the Swinging London.

Youth subcultures use appearance as a way of contestation, processing part of the social and cultural revolution, which began in the 50s and broke out in the 60s. The democratization of ready-to-wear, with its driving force of rising consumption over the growing youth culture, is influenced by street fashion, thus Paris loses its hegemony, sharing space with designers from other countries. As a result of this process, fashion becomes an international phenomenon. Thereby, advertising agencies and fashion editors introduce this new aesthetic in magazines.

\section{Purpose and Method: Analysis Through The Drapers' Record Magazine}

\footnotetext{
Maíra Zimmermann, Lecturer in Fashion and Design, Armando AlvaresPenteado Foundation (FAAP); Ph.D. in History, State University of Campinas (Unicamp).
} 
This paper discusses how consumerism boosted youth lifestyle, and built a territorial symbolic identity through fashion. The importance of systematizing fashion trends can be noticed since the 19th century. The weekly British journal The Drapers' Record (which was first published in 1887 and is still active), was used as primary source for understanding this process. Its content introduced textile and clothing store industries to the British retail sector.

The magazine shows ads, fashion editorials, mainly female, articles and news about fashion trend. Most pictures are black and white. There is also a brands guide for shoppers and retailers, organized into categories such as: jeans, dresses, suits, maternity clothing, women, girls, men and boys clothing. The magazines used in the research are from 1964 to 1967, July and August issues, when the fall-winter trends are shown.

Most ads found in the magazines are by synthetic fabric and knitwear manufacturers. Orlon and Courtelle acrylic fibers are frequent advertisers. Ads for hats, lingerie, bedlinen, children and teenagers uniforms can also be found. After 1964, we notice the orientation towards a young market and style, but these trends will fully materialize through 1967.

\section{Making the Young British Style}

British youth fashion in the 1950's was heavily influenced by North America: College, Western and Rock'n'roll styles. In the 60's, however, the Continental style can already be noticed in trend analysis. According to an article from 1964, young people are leaving behind North American style for French influences. The mod style - inspired by French and Italian fashion - is the latest trend.

This style has particular subdivisions such as the Faces, the Stylists - the largest group - and the Tickets. The French influence can be seen in the berets collection launched by hats brand Kangol: "As seen in Paris. Paris has set the trend - the beret is in!" - says the ad. However, the North American influence is still there, with lots of denim pieces on the market: in July 1964 Blue Bell Apparel launched denim shorts and jeans.

Drapers' Record ads also begins to show the mod style. The mod subculture started in the end of the 1950's as a style adopted by a few young working class people. In the 60's, the media starts calling it a trendsetter. This fashionable look could now be found ready to wear at British stores. Duke Sportswear's fall collection ad shows a young model smiling, hands on hips and head slightly cocked. A look that clearly reflects the mod trend: long neck sweater and a woolen pleated skirt. She also has a mod style haircut: long bob with bangs.

Successful designer, Mary Quant is an example of young style consolidation. In November 1955, Quant and her husband Plunket Greene teamed up with a friend, Archie McNair, to open Quant's first shop, Bazaar, on King's Road. In 1962, Quant signed a lingerie and clothing licensing deal with J.C. Penney and expanded her business on to the United States. In 1963, she founded the Mary Quant Ginger Group Wholesale Clothing Design and Manufacture Company.

In 1965 she teamed up with Courtelle to promote the sales of wool and hand knitting. In a colorful booklet inserted in Drapers' Record, the company shows 27 easy-to-make patterns designed by Mary Quant. "The most exciting trend-setter in the fashion world today"-says the booklet. It also points out that the looks were created with Hand knitting Courtelle, and that "it's economical, easy to work with and produces knitted and crochet fashions that are so soft, yet keep their shape and vibrant colors through wash and wear".

We may say that Mary Quant advertised not only a style but also a graphic language that communicated with young people through appeal and attractive shapes and forms. By the time Quant teamed up with Courtelle, in 1965 she was already famous and her name had already been associated with the daisy logo. At that time, 
however, the daisy was drawn in irregular lines with a red outline. In 1966 the Courtelle patterns drawn by Mary Quant were still being published. The visual identity adopted by the brand changes though. The daisy logo is modernized and now has a regular schematic shape, with a black center and white petals.

This floral pattern became a trend and could be found in some other products, here are two examples:

(1) In 1965, Sunarama House launches the BriNylon floral patterned tights, called Daisy Lace.

(2) In 1967, an article called "Flower show" introduces the readers to a "showerproof coat for high summer from a group of ten canvas styles in bright colors", by Cordoba. The coat in the ad picture shows patters clearly inspired by Mary Quants daisies, which goes to show the visual identity penetration developed by the designer's brand.

The article entitled "Paris no longer the oracle" reveals that fashion trends are coming from different centers. London is definitely included in the scene, as well as the United States and Italy. However, the Space Age style created by André Courrèges and Pierre Cardin, keeps Paris as the most important fashion trendsetter. According to the article, despite Paris innovations, London was very active too. It is also interesting to observe that at this time, traveling starts to be part of the designers' way of life and that allows them to get in touch with different styles and influences. The North American influence in sports style and casual clothing is noticed as well as the presence of a "pop fashion" brought by the young. The article finally says: "The result is that Paris is no longer the oracle it used to be".

British clothing manufacturer Slimma Group is mentioned as being the first manufacturer to introduce young styled trouser suits, tunics, tiers, pajama pants and stocking keyed to match outfits. In fact, Slimma presents clothing and publicity aimed at a young public, with skirts slightly above the knees and slack style pants. Although still wearing a conservative skirt, the model in the ads shows juvenile hairstyle, make up and attitude.

\section{Fashion Juvenilization Through Drapers' Record}

Drapers' Record covers between 1964 and 1965 show how fast fashion styles got younger.

In 64, we found more conservative styles:

- One cover shows: Daydream sheets advertised by a woman lying alone in her bed, under yellow sheets matching her ruffled sleeved nightgown. The atmosphere is romantic and intimate, there are flowers in her bedroom, a cup of tea on the nightstand and a book on the bed. The ad seems to suggest the connection between the intimate space of a home and a "feminine essence". The cover reads: "This is the look of Daydream. Calculated to appeal to a woman's heart".

- Other covers from 64 also show conservative looks: elegant women wearing overcoats, Chanel style tailleurs and hats.

Despite the more conservative covers, in August of 1964 the youth style starts to show its penetration: Patons yarns creates an ad showing a young model in a casual pose (she wears her hair tied up in a headband, bangs, make up with eyeliner and voluminous eyelashes, an orange turtleneck blouse, a tone on tone wool V neck sweater, and white trousers, a very young and fresh look).

Trough 1965 the covers get even younger: In July, we see a couple posing as if they are moving around in a field (by Paton yarns), another cover shows a model with her head held high: She is wearing a black and white sweater and white trousers and boots, behind her there is a man watching her, he is wearing something from Mars maybe, a white hood, bringing to mind the Space Age style (by acrylic fiber Orlon).

In July 66, a black and white cover shows a very elegant model in an overcoat, carrying a suitcase showing 
"Miss Smith" blue logo. Despite an overall elegant and conservative look, her attitude suggests movement as if she is climbing stairs, her makeup and long bob hair with bangs are very "up-to-date". In July 67, "Miss Smith" coats and suits brand adopt a more modern look, that can also be seen in the bold typography. The covers start to show life, color and movement.

Between 1965 and 1967 fashion juvenilization reached its peak. Synthetic fiber manufacturer Orlon invested in young and bold ads. In the following ads, we can see: a very happy Jean Shrimpton interacting with her partner and also Space Age looks, again Jean Shrimpton showing a very bold knee, and a model showing an ironic "baby style" with a huge ribbon in her hair. There are also colorful advertorials with lots of pictures taken in places such as Turkey and Greece.

The magazine articles keep referring to the young fashion that is now more popular than ever. In a Drapers' article from July 1965 we can read "Paris woos the Young", also Mary Quant continues to offer Courtelle wool pattern deals, the mod look can be seen in clothing ads, such as Stella knitwear, which presents "A new look at a classic style" and, after 1966, the skirts get shorter and shorter. Some brands stand out for being exclusively young fashion brands, such as stockhouse Raysil. The cool ads appeal to the In girl: "Raysil girls lead the young set, Raysil girls all the fun get", showing outfits like a collarless blazer with a godet mini skirt and a psychedelic tight mini turtleneck dress with floral pattern.

After July 1966 and trough 1967, geometric shapes and psychedelic multicolor floral patterns start to appear in articles and ads. Since then, more and more brands focus specifically on young people: in July 1966, Vogue magazine and Hayfiel Wool launch a campaign with outfits designed by the yarn brand to be published in Vogue's knitting book; one of the leading models is the super young model Twiggy. Ads of color tights and articles on comfortable casual wear also appear in the magazine.

Still in 1966 it was possible to find several ads with bright colored clothes, such as: Orlon's pink dress, worn by a model photographed in Greece, and also colorful fabrics, like the Dacron's intense floral patterns. But it is in 1967 that we have the peak of the bold young style, based on psychedelic Swinging London's and hippie North American style. In July 1967, even Vantona's bedlinen follows the "exotic" trend, showing a blonde model, wearing straight hair with bangs, strong eyeliner and doll eyelashes (a style widely advertised by Twiggy), the model is under a bright blue bedspread with green spots. In a systematic way, we found:

- different patterns: multicolor, geometric, stripes and circles, floral, organic, paisley;

- bold clothes: stomach showing crochet dresses, miniskirts and mini dresses, shorts, jeans, trapezium dresses;

- perky accessories such as pantyhose, boots, doll and flat shoes and juvenile hair and makeup: geometric haircuts, eyes with strong eyeliner and doll eyelashes.

\section{Conclusion}

The invasion of all these multicolor and often disposable products that made up the young style and appealed so much to young people, is not only an indicator of fashion changes but also of a cultural and social revolution that society went through after the end of World War II. Historian Eric Hobsbawn refers to these changes in his book The Age of Extremes. The systematic implementation of the young style by the industry may be verified through image analyses of a primary source, a magazine, that reveals to the researcher the importance of fashion not only as an indicator of taste changes but also as part of the transformation and making of cultural history. 


\section{References $^{1}$}

Baudot, F. (2002). Moda do século (Fashion: The twentieth century). São Paulo: Cosac \& Naify.

Breward, C. (1995). The culture of fashion: A new history of fashionable dress. Manchester: Manchester University Press.

Breward, C., Gilbert, D., \& Lister, J. (2006). Swinging sixties: Fashion in London and beyond-1955-1970. London: V\&A Publishing.

Callan, G. O. H. (2007). Enciclopédia da moda: de 1840 à década de 90 (Fashion encyclopedia: From 1840 until the 90 s). São Paulo: Companhia das Letras.

Groppo, L. A. (2000). Juventude: ensaios sobre sociologia e história das juventudes modernas (Youth: Essays on sociology and history of modern youths). Rio de Janeiro: Difel.

Hebdige, D. (1979). Subculture: The meaning of style. England: Routledge.

Hobsbawm, E. (1995). Era dos extremos: o breve século XX 1914-1991 (The age of extremes: A history of the world, 1914-1991). São Paulo: Companhia das Letras.

Lester, R. (2010). Boutique London-A history: King's Road to Carnaby Street. England: ACC Editions.

Lipovetsky, G. (2006). O império do efêmero: a moda e seus destinos nas sociedades modernas (The empire of fashion: Dressing modern democracy). São Paulo: Companhia das Letras.

Maffesoli, M. (1987). O tempo das tribos: declínio do individualismo nas sociedades de massa (The time of the tribes: The decline of individualism in mass society). Rio de Janeiro: Forense-Universitária.

Marwick, A. (1998). The Sixties: Cultural revolution in Britain, France, Italy and the United states, c.1958-c.1974. England: Oxford.

McCracken, G. (2003). Cultura \& consumo (Culture and consumption). Rio de Janeiro: Mauad.

Mendes, V., \& Haye, A. (2003). A moda do século XX (20th Century Fashion). São Paulo: Martins Fontes.

Morin, E. ([1962] 1975). Cultura de massas no século XX: o espírito do tempo (Mass culturein the twentieth century: The spirit of the time). Rio de Janeiro: Forense-Universitária.

O’Neill, A. (2002). John Stephen: uma apresentação de masculinidade da Carnaby Street 1957-1975 (John Stephen: A Carnaby Street presentation of masculinity 1957-1975). Fashion Theory, I(4), 119-38.

Perry, G. (2001). London in the sixties. London: Pavilion.

Polhemus, T. (1994). Street style: From sidewalk to catwalk. New York: Thames and Hudson.

Savage, J. (2009). A criação da juventude: como o conceito de teenage revolucionou o século XX (Teenage: The prehistory of youth culture: 1875-1945). Rio de Janeiro: Rocco.

\footnotetext{
${ }^{1}$ Researched archives: Archive Blythe House-Archive of Art and Design_Victoria \& Albert Museum (V\&A). The Wookmark Archive (London College of Fashion): The Drapers' Record - British textiles, women's wear \& drapery news (1964-1967); Mary Quant Collection (garment and examples of make-up from the 1960's)
} 